\title{
Agriculture of the middle participation in state branding campaigns: The case of Kentucky
}

\author{
Alicia M. Hullinger ${ }^{a *}$ and Keiko Tanaka ${ }^{b}$ \\ University of Kentucky
}

Submitted April 14, 2014 / Revised September 22 and November 1, 2014, and

July 24, 2015 / Accepted July 27, 2015 / Published online December 3, 2015

Citation: Hullinger, A. M., \& Tanaka, K. (2015). Agriculture of the middle participation in

state branding campaigns: The case of Kentucky. Journal of Agriculture, Food Systems, and

Community Development, 6(1), 107-120. http://dx.doi.org/10.5304/jafscd.2015.061.008

Copyright (C) 2015 by New Leaf Associates, Inc.

\begin{abstract}
In the past decade, statewide agricultural branding campaigns have blossomed. Examining the case of the Kentucky Proud ${ }^{\mathrm{TM}}(\mathrm{KyP})$ program, this paper investigates the potential benefit of a state-level marketing strategy for the declining class of midsize farms, referred to as Agriculture of the Middle (AOTM). First, we discuss why AOTM farms are important to maintaining a viable agriculture structure. Second, we introduce the context of state branding and explain how KyP developed as part of the transition from highly tobacco-dependent agriculture. Using recent agricultural census data and a survey of $\mathrm{KyP}$ members, we compare the key characteristics between three sets of pairs: (a) U.S. AOTM

a * Corresponding author: Alicia M. Hullinger, Department of Sociology, University of Kentucky; 1515 Patterson Office Tower; Lexington, Kentucky 40506-0027 USA: alicia.hullinger@uky.edu

b Department of Community \& Leadership Development, University of Kentucky; 500 Garrigus Building; Lexington, Kentucky 40546-0215 USA; ktanaka@uky.edu
\end{abstract}

farmers and Kentucky AOTM farmers, (b) Kentucky AOTM farmers and $\mathrm{KyP}$-member AOTM farmers, and (c) KyP AOTM farmers and other KyP-member farmers. The findings indicate that Kentucky's AOTM farmers are unique compared to U.S. AOTM farmers, and that the $\mathrm{KyP}$ program benefits particularly those AOTM farmers transitioning from tobacco-dependent agriculture. We also found that the logo of the state branding campaign helps member farmers differentiate their products, and that the program helps most members gain knowledge and skills for marketing their products. Overall, findings suggest that state branding campaigns designed to incentivize agricultural marketing of local foods have the potential to help farmers of the middle. Further research needs to be done in order to track the long-term impact of different agricultural branding campaigns.

\section{Keywords}

state branding program, impact analysis, agriculture of the middle (AOTM) 


\section{Introduction: State Branding Campaigns}

Since the 1930s, state governments have been involved in marketing and differentiating agricultural products through commodity commissions and marketing boards (e.g., Washington apples, Maine potatoes, and California peaches), in part to stabilize overstrained market conditions after the Great Depression. By the 1980s, the focus of state branding programs began to shift from one specialized commodity, such as Washington apples, or category of products, such as Wisconsin cheese, to any agricultural products produced in a state so as to create economic opportunities for farmers struggling to survive the farm crisis (Patterson, 2006). In the early 2000s, the availability of federal block grants (e.g., those made available through the Agricultural Producers Marketing Assistance Act of 2001) apportioned for specialty crops resulted in a surge of state-led agricultural branding programs, each with a distinctive logo to market locally produced agricultural and food products. By 2006, as many as 44 states had established state branding programs, as compared to about eight states in the 1980s (Patterson, 2006).

According to Hinrichs and Jensen (2006), there are three dominant objectives in state branding programs: (1) to promote a state's agricultural products, (2) to increase consumer awareness and consumption of those products, and (3) to develop markets and businesses within the state. The majority of these programs define "local" food as those products grown, raised, or processed within the state, and market those products as "superior quality" and "fresh." The definition for "local" for a significant number of states is based on a certain percentage of the product, measured by either weight or value, that has its production process take place within the state (Fisher, 2012). Regardless of the definitions or guidelines for "local" food, each state branding program aims to support that state's agricultural sector and food industry by expanding marketing opportunities for farmers within the state.

Given the level of public investment, understanding the impact of state-sponsored agricultural branding programs is important. In the existing research literature, the benefits of marketing and branding programs have been examined from three angles. First, consumercentric studies have focused on the factors that contribute to levels of consumer awareness (Carpio \& Isengildina-Massa, 2009a; Govindasamy, Italia, \& Thatch, 1999; Hu, Onozaka, \& McFadden, 2011) and appropriate pricing of branded products (Carpio \& IsengildinaMassa, 2009b; Onken, Bernard, \& Peskek, 2011). Second, farmercentric research has shown that producer awareness levels and perceptions of statesponsored programs affect the rate of program participation (Davis 2012; Velandia et al., 2012). The impact of promotional expenditures on farm cash receipts and farm business income is also an important factor in the program benefits (Govindasamy et al., 2004; Uematsu \& Mishra, 2011). Third, research on the economic impact of state branding campaigns has shown a positive benefit on both the overall and agricultural economy in the state. For example, an economic evaluation of Kentucky Proud ${ }^{\text {TM }}$ (KyP) from 2004 to 2006 (Infanger, Maurer, \& Palmer, 2008) found that each dollar invested in the $\mathrm{KyP}$ marketing program returned US $\$ 5.20$ in net benefits to the economy and between US\$2.89 to US\$3.39 in net cash income to farmers.

In this exploratory study, we look at the impact of Kentucky's state branding program, Kentucky Proud $^{\mathrm{TM}}$, on the state agriculture of the middle (AOTM), a "disappearing sector [in the U.S.] of mid-scale farms and related agrifood enterprises that are increasingly unable to successfully market bulk agricultural commodities or sell products directly to consumers" (Lyson, Stevenson, \& Welsh, 2008, p. xiii). In order to conduct our assessment, this case study uses national- and statelevel data from the U.S. Census of Agriculture for the years 2002 and 2012, and data from a randomsample survey of KyP members conducted in 2011. This paper is organized into five sections. In the first section, we briefly discuss why it is important to focus on AOTM farms in examining the impact of state branding programs. Second, we present the background of the development of the KyP program. Third, we explain our research design. Fourth, we present our findings, comparing the key characteristics between three sets of pairs: (a) U.S. AOTM farmers and Kentucky AOTM farmers, (b) Kentucky AOTM farmers and KyP member 
AOTM farmers, and (c) KyP AOTM farmers and other KyP member farmers. We conclude by highlighting the potential and opportunities for the state's role in supporting AOTM, recommending that policy-makers keep in mind that scale matters.

\section{Why Agriculture of the Middle?}

To examine impacts of a state branding program, this study focuses on AOTM, because these farms contribute to positive social, economic, and environmental outcomes in their community and state. Existing studies (see Goldschmidt, 1978 [1947]; Green, 1985; Kirschenmann \& Stevenson, 2015; Lobao, Schulman, \& Swanson, 1993; Peters, 2002) show that midsize farms are particularly critical in contributing to the economic and social viability of rural America by circulating money in local economies, preserving open space, providing environmental benefits, attracting tourists, and upholding quality life. These scholars maintain that AOTM farms are uniquely vital and valuable to U.S. agriculture.

Generally, AOTM farms are characterized by (a) their size, measured by annual gross sales (AGS) between US\$50,000 and US\$499,999; (b) their business organization, defined by the U.S. Department of Agriculture (USDA) as either "farming occupation farms" or "large family farms" category; and (c) their production and marketing strategies (Kirschenmann, Stevenson, Buttel, Lyson, \& Duffy, 2013). As AOTM researchers emphasize regarding the definition of AOTM farms and ranches, "while it is not scale determined, it is scale related" (Kirschenmann, Stevenson, Clancy, Marlow, Simmons, Smith, \& Yee, 2013, p. 1).
The 2012 Census of Agriculture shows that nationally AOTM farms make up $17.6 \%$ of all farms, produce $16.4 \%$ of farm sales, and manage $35.1 \%$ of farmland (Table 1). A large percentage of the value of agricultural production is generated by a small number of large- and very-large-scale farmers, or $7.6 \%$ of farms, grossing over US $\$ 500,000$ in annual sales and capturing $80.7 \%$ of total farm sales. These same farms own $38.4 \%$ of all farmland. There is evidence that the domination of sales by the segment of U.S. farms that are large and very large is growing (MacDonald, Korb, \& Hoppe, 2013). These national trends raise concern about maintaining the vitality of agriculture in state and local economies.

Access to appropriate markets is an important aspect of maintaining a farm as an economically viable enterprise. Direct-to-consumer markets such as farmers markets and community supported agriculture operations (CSAs) may be too small for some AOTM farmers to sell all their products, while global commodity markets are too capital-intensive for other midsize farms, yielding little return on investment. The vibrancy of AOTM therefore depends largely on production and marketing strategies that midsized farmers can adopt to differentiate their value-added products in the market. Values-based supply chains, food hubs, and producer or consumer cooperatives are among marketing strategies that have been reported to potentially benefit AOTM (Clancy, 2010; Diamond \& Barham, 2011; Hinrichs \& Lyson, 2007; Lev \& Stevenson, 2013; Stevenson, 2009). To our knowledge, no research has been done on state branding marketing campaigns as a potential strategy for AOTM farms. To be consistent with this work, we follow the definition of AOTM by sales category (AGS between US $\$ 50,000$ and US $\$ 499,999)$ in order to assess the impact of the $\mathrm{KyP}$ program on AOTM farmers. 


\section{Background of Kentucky Proud}

Kentucky ranks fourth among the states in number of farms (USDA-NASS, 2012). For centuries, numerous livelihoods across Kentucky depended on growing burley tobacco. The end of the federal tobacco program initiated a series of recent transformations in Kentucky agriculture and created the need for building a new agricultural economy. In 2000, the state General Assembly instituted the Governor's Office of Agricultural Policy (GOAP) and the Kentucky Agriculture Development Board (KADB) to distribute $50 \%$ of the state funds from the Master Settlement Agreement with the tobacco industry among projects that support the development of a new agricultural economy (GOAP, n.d.). The creation in 2004 of Kentucky Proud (KyP), a state branding program, was one of these projects explicitly designed to facilitate the transition of tobacco-dependent farmers and communities to new agricultural products and/or ventures (Caporelli, 2011).

The $\mathrm{KyP}$ program is administered by the Kentucky Department of Agriculture (KDA). The definition of a $\mathrm{KyP}$ product is written in state statutes as "any agricultural product grown, raised, processed, or manufactured in Kentucky" (Definitions, 2015). (Kentucky has not set a percentage requirement, however, for the state of origin for $\mathrm{KyP}$ products.) The program uses a KyP logo to promote Kentucky agricultural products, which appears widely on TV and in print advertisements as a means to increase consumer awareness about how "supporting Kentucky's farm families... [and]... building a sense of community" strengthens the local economy, and purchasing $\mathrm{KyP}$ products makes an "investment in Kentucky's land, people, and its future" (Kentucky Department of Agriculture, n.d., "Kentucky Proud," para. 1).

The program offers various resources and financial incentives to qualifying members to expand marketing of $\mathrm{KyP}$ products, including point-of-purchase grants, restaurant rewards, brand and advertising funds, trade-show funds, meat grader training, retail negotiation training, and distributor coordination. The KyP program offers financial incentives to participating members based on direct farm impact. For example, $\mathrm{KyP}$ restaurant and food institution members turn in cash receipts of local food purchases, or Kentucky agricultural products and agriculture-related valueadded products that have direct farm impact, to receive a reimbursement of up to US $\$ 12,000$ a year. The Point-of-Purchase Grant Program helps defray marketing costs for members who use the $\mathrm{KyP}$ label. For example, a KyP member who uses the logo to advertise point-of-purchase or sales items can qualify for financial reimbursement by turning in a receipt showing purchase of the marketing item, such as a sign with the KyP logo on it to be used at the Lexington Farmers' Market. A $\mathrm{KyP}$ member can be reimbursed for up to $50 \%$ of eligible marketing expenses. Again, direct farm impact, as reported by the member, is a crucial component in determining the amount of an awarded grant.

The number of $\mathrm{KyP}$ participants (growers, producers, retailers, and institutions) has grown rapidly, from roughly 30 in 2004 to 2,800 in 2011. Findings from a previous evaluation of the $\mathrm{KyP}$ program indicate that the main reason given by participants to join the state-sponsored program is to "increase consumer awareness for my product" (Fisher, 2013, p. 57). Other motivations cited in this evaluation include the opportunity to gain brand recognition, the incentive to gain financial benefits, and the desire to be part of the local food movement. According to KyP members in this study, the campaign has successfully increased consumer awareness for $\mathrm{KyP}$ products and has been fairly effective in providing members with the necessary education and tools to improve their marketing skills. According to a consumer awareness survey conducted by the KDA, a majority of Kentucky consumers are indeed aware of the $\mathrm{KyP}$ label, and the main motivation for consumers to purchase a $\mathrm{KyP}$ product is to support Kentucky farm families (Fisher, 2012).

Many KyP members recognize that the inclusive definition of what constitutes a $\mathrm{KyP}$ product— "agricultural products that have been grown, raised, processed, or [emphasis added] manufactured in the state"-leads to unintentional leakages of potential economic benefits of the brand, decreasing the multiplier effect (Fisher, 2012). On the other hand, this inclusivity keeps down the cost of the state branding program 
because it does not require extensive accreditation and monitoring. In short, the KyP program can be an economic benefit for producers who participate in the marketing strategies by way of brand recognition. Our research investigates whether AOTM farmers specifically benefit from the $\mathrm{KyP}$ program.

\section{Methods}

In order to evaluate the impact of the $\mathrm{KyP}$ on the "disappearing" AOTM in Kentucky, we relied on two sets of existing data: Census of Agriculture data from 2002 and 2012, and the data from the random probability sample survey conducted in 2011 by Fisher (2012).

First, the 2002 Census of Agriculture data were used for an analysis to compare data for the KyP program, which started in 2004 (Table 2). Using the 2002 and 2012 Census of Agriculture data, the 11 categories designating farm operators based on agricultural sales were recoded into two categories for analysis: "All farms" and "AOTM farms." The U.S. AOTM was included for comparison to illustrate the locally specific, unique characteristics of Kentucky AOTM. The data collection methods for the 2002 and 2012 data were the same for the variables used in our analysis, except "Organic sales." (Data on the value of certified organic products were collected for the first time in 2002. In the 2007 and 2012 census years, data were collected for products conforming to USDA National Organic Program Standards, permitting reasonable comparison between these two census periods.)

Three types of variables from the Census of Agriculture were used for analysis of Kentucky AOTM:

(a) Characteristics of farm operations, including Average Farm Size, Number of Farms, Land in Farms, Total Sales, and Tobacco Sales;

(b) Use of "alternative" farming practices to differentiate and add value to farm products, including Direct to Consumer Sales, Agritourism, and Organic Sales;

(c) Use of a "conventional" farming practice, as measured by the total acreage treated with Commercial Fertilizers, Lime, and Soil Conditioners (labeled as "Chemical Fertilizer" in Table 2).
Following the methodology of the University of Minnesota Food Industry Center (2014), we selected these variables as food system indicators that measure structural, economic, environmental, and social changes in the food system. In order to illustrate Kentucky's unique regional differences, the U.S. AOTM is used as comparison.

Second, the data from the KyP-member survey were used to identify characteristics of KyP AOTM farmers' operations. The survey consisted of 54 questions and included both close-ended and open-ended questions, with demographic questions at the end (Appendix A). The survey was designed to learn more about the beliefs, practices, and motivations of KyP members.

Using the tailored design method (Dillman, Smyth, \& Christian, 2008), randomly selected KyP members were contacted five times through different methods. A self-administered mail survey and/or Qualtrics ${ }^{\circledR}$ online survey collected data from 597 of 2,548 KyP farmer members $(23.4 \%$ total response rate) who were asked to participate. Generally, farmers tend to have a low response rate, ranging from $10 \%$ (Walz, 2004) to $38 \%$ (Timms \& Schulte, 2013). For a random-sample survey, the number of responses for this study is large enough to make statistical generalizations. After dropping cases for missing data, the responses from 320 of 597 survey participants were included for analysis, reducing the final response rate to $12.6 \%$ (320 out of 2,548 surveys sent). Of $320 \mathrm{KyP}$ farmers who participated in the survey, 59 $(18.4 \%)$ can be categorized as AOTM farmers.

Table 3 summarizes the key sociodemographic characteristics of the survey participants. We compared operation characteristics of KyP AOTM respondents to those of Kentucky AOTM farmers based on the 2012 U.S. Census of Agriculture. We then compared the KyP AOTM group with all KyP farmers who participated in the survey. Despite the end of the federal tobacco program, tobacco continues to play an important part in Kentucky's agricultural landscape. We therefore used tobacco affiliation (i.e., whether or not producing tobacco, presently or in the past) to identify the crop's significance for $\mathrm{KyP}$ AOTM farmers. Whether or not a farm is certified with Good Agricultural 
Table 2. Key Characteristics of AOTM Farm Operations in the U.S. and Kentucky, 2002 and 2012

\begin{tabular}{|c|c|c|c|c|}
\hline & \multicolumn{2}{|c|}{2002} & \multicolumn{2}{|c|}{2012} \\
\hline & U.S. & KY & U.S. & KY \\
\hline \multicolumn{5}{|l|}{ Average Farm Size } \\
\hline AOTM average (acreage) & 1,142 & 491 & 864 & 401 \\
\hline$\%$ change in AOTM acreage & & & $-24.3 \%$ & $-18.3 \%$ \\
\hline \multicolumn{5}{|l|}{ Farm Number } \\
\hline AOTM total (farms) & 391,272 & 7,812 & 371,316 & 8,721 \\
\hline$\%$ of AOTM of total farms & $18.4 \%$ & $9.0 \%$ & $17.6 \%$ & $11.3 \%$ \\
\hline$\%$ change in AOTM farms & & & $-5.1 \%$ & $11.6 \%$ \\
\hline \multicolumn{5}{|l|}{ Land in Farm } \\
\hline AOTM total (1,000s acres) & 446,702 & 3,837 & 320,727 & 3,521 \\
\hline$\%$ of AOTM of total farm land & $47.6 \%$ & $27.7 \%$ & $35.1 \%$ & $27.0 \%$ \\
\hline$\%$ change in AOTM farm land & & & $-28.2 \%$ & $-8.2 \%$ \\
\hline \multicolumn{5}{|l|}{ Cropland Harvested } \\
\hline AOTM total (1,000s acres) & 171,474 & 1,984 & 95,931 & 1,605 \\
\hline$\%$ of AOTM of total cropland & $56.7 \%$ & $39.8 \%$ & $30.5 \%$ & $30.0 \%$ \\
\hline$\%$ change in AOTM cropland & & & $-44.1 \%$ & $-19.1 \%$ \\
\hline \multicolumn{5}{|l|}{ Total Sales } \\
\hline AOTM total (in $\$ 1,000$ s) ${ }^{1}$ & $80,368,268$ & $1,418,089$ & $64,547,130$ & $1,270,683$ \\
\hline$\%$ of AOTM of total sales & $56.7 \%$ & $36.1 \%$ & $16.4 \%$ & $25.1 \%$ \\
\hline$\%$ change in AOTM total sales & & & $-19.7 \% \%$ & $-10.4 \%$ \\
\hline \multicolumn{5}{|l|}{ Tobacco Sales } \\
\hline AOTM total (farms) & 11,062 & 4,200 & 5,146 & 4,530 \\
\hline$\%$ of AOTM of all farms reported & $19.5 \%$ & $53.8 \%$ & $51.5 \%$ & $50.1 \%$ \\
\hline$\%$ of AOTM reported of total AOTM farms & $2.8 \%$ & $53.8 \%$ & $1.4 \%$ & $51.9 \%$ \\
\hline$\%$ change in AOTM tobacco farms & & & $-53.5 \%$ & $7.9 \%$ \\
\hline \multicolumn{5}{|l|}{ Direct to Consumer Sales } \\
\hline AOTM total (farms) & 15,333 & 284 & 21,547 & 414 \\
\hline$\%$ of AOTM of all farms reported & $13.1 \%$ & $11.1 \%$ & $14.9 \%$ & $12.0 \%$ \\
\hline$\%$ of AOTM reported of total AOTM farms & $3.9 \%$ & $3.6 \%$ & $5.8 \%$ & $4.7 \%$ \\
\hline$\%$ change in AOTM direct to consumer farms & & & $40.5 \%$ & $45.8 \%$ \\
\hline \multicolumn{5}{|l|}{ Agri-tourism } \\
\hline AOTM total (farms) & 8,544 & 75 & 6,971 & 74 \\
\hline$\%$ of AOTM of all farms reported agri-tourism & $30.5 \%$ & $17.8 \%$ & $44.3 \%$ & $11.4 \%$ \\
\hline$\%$ of AOTM reported of total AOTM farms & $2.2 \%$ & $1.0 \%$ & $1.9 \%$ & $0.8 \%$ \\
\hline$\%$ change in AOTM agri-tourism farms & & & $-18.4 \%$ & $-1.3 \%$ \\
\hline \multicolumn{5}{|l|}{ Organic Sales } \\
\hline AOTM total (farms) & 2,118 & 26 & 5,627 & 34 \\
\hline$\%$ of AOTM of all farms reported & $17.7 \%$ & $5.0 \%$ & $17.7 \%$ & $39.5 \%$ \\
\hline$\%$ of AOTM reported of total AOTM farms & $0.5 \%$ & $0.3 \%$ & $1.5 \%$ & $1.0 \%$ \\
\hline$\%$ change in AOTM organic sales farms & & & $165.7 \%$ & $30.8 \%$ \\
\hline \multicolumn{5}{|l|}{ Chemical Fertilizer2 } \\
\hline AOTM total (1,000s acres) & 138,555 & 1,646 & 76,172 & 1,192 \\
\hline$\%$ of AOTM acreage of total acreage & $55.9 \%$ & $41.6 \%$ & $30.7 \%$ & $31.5 \%$ \\
\hline$\%$ of AOTM acreage of total AOTM cropland & $31.0 \%$ & $83.0 \%$ & $23.8 \%$ & $74.3 \%$ \\
\hline \% change in AOTM acreage & & & $-45.0 \%$ & $-27.6 \%$ \\
\hline
\end{tabular}

Sources: U.S. Census of Agriculture (2002, 2012). Notes: 1. Total Sales (in US\$1,000s) adjusted for inflation to 2012 real dollars. 2. "Chemical fertilizer" comes from the data labeled "Commercial fertilizer, lime and soil conditioners" in the U.S. Census of Agriculture. 
Practices (GAP) certification ${ }^{1}$ is used as a measure for environmental stewardship, contributing to potential added value of products.

As dependent variables, we used the presence or absence of economic gain (Change in Sales) and program benefit (Program Marketing Value) as shown in Table 4. Chi-square tests were used to analyze the link between these two sets of dependent and the following independent variables: different types of products sold as income, market outlets used to sell products, and marketing practices products sold as income.

There are some limitations to this study. The first limitation, among the survey data, is the small number of KyP AOTM farmers $(N=59)$ after dropping nonfarmers and missing data. The second survey data limitation is the difference in data collection periods. The KyP member survey data were collected in 2011 while agriculture census data were collected in 2012. While the KyP survey response rate is low and could potentially lead to nonresponse error, the response rate is considered good for a population that tends to be surveyed frequently. Despite these limitations, the methodology is a first attempt to disaggregate state-level data in order to better understand AOTM dynamics,

Table 3. Key Characteristics of the 2011 Kentucky Proud (KyP) Survey Participants ( $N=320$ ), in Comparison to Kentucky AOTM Farmers in the 2012 U.S. Census of Agriculture

\begin{tabular}{|c|c|c|c|c|}
\hline & & $\begin{array}{c}\text { KyP } \\
\text { All a } \\
(N=320)\end{array}$ & $\begin{array}{c}\text { KyP } \\
\text { AOTM a } \\
(N=59)\end{array}$ & $\begin{array}{c}\text { Kentucky AOTM b } \\
(N=8,721)\end{array}$ \\
\hline Percent of Total ${ }^{*}$ & & $100 \%$ & $18.4 \%$ & $11.3 \%$ \\
\hline \multirow[t]{2}{*}{ Farm Size (acres) } & Mean & 86.8 & 368.5 & 401 \\
\hline & $\mathrm{SD}^{1}$ & 159.3 & 422.3 & \\
\hline \multirow[t]{2}{*}{ Age (years) } & Mean & 61.5 & 66.3 & 56.7 \\
\hline & SD & 11.7 & 14.1 & $\mathrm{~N} / \mathrm{A}$ \\
\hline \multirow[t]{2}{*}{ Education (years) } & Mean & 15.12 & 15.14 & N/A \\
\hline & SD & 2.48 & 2.76 & \\
\hline White (yes) & $\%$ & $95.2 \%$ & $94.9 \%$ & $99.6 \%$ \\
\hline Female (yes) & $\%$ & $44.2 \%$ & $27.1 \%$ & $5.4 \%$ \\
\hline Rural County (yes) & $\%$ & $31.0 \%$ & $30.5 \%$ & N/A \\
\hline Tobacco Affiliation (yes) & $\%$ & $45.9 \%$ & $66.1 \%$ & $50.1 \%$ \\
\hline GAP Certification (yes) & $\%$ & $38.4 \%$ & $38.6 \%$ & $\mathrm{~N} / \mathrm{A}$ \\
\hline \multirow[t]{2}{*}{ Total Sales } & Mean & 82,033 & 135,834 & 145,704 \\
\hline & SD & 465,917 & 80,264 & \\
\hline Direct to Consumer Sales (farms) & $\%$ & $85.9 \%$ & $84.7 \%$ & $12 \%$ \\
\hline Agri-Tourism (farms) & $\%$ & $16.6 \%$ & $23.3 \%$ & $11.4 \%$ \\
\hline Organic Sales (farms) & $\%$ & $32.2 \%$ & $32.2 \%$ & $39.5 \%$ \\
\hline Chemicals-Fertilizer (farms) & $\%$ & $60.6 \%$ & $76.3 \%$ & $31.5 \%$ \\
\hline
\end{tabular}

Source notes: a Fisher, 2012. b U.S. Census of Agriculture, 2012.

Notes: $\mathrm{SD}=$ Standard Deviation; $*$ $p<0.01$

${ }^{1}$ Along with Good Handling Practices (GHP) Certification, the USDA began implementing GAP in 2002 to ensure that fruits and vegetables are produced, handled, and stored in the safest manner to reduce food safety risks. The GAP/GHP audits are designed to improve agriculture sustainability by encouraging farmers to adopt farming practices that conserve natural resources, improve food quality and safety, as well as working conditions of farm laborers, create new market opportunities for farmers, and improve traceability of their farm products in the supply chain. 
making a contribution to previous scholarship and opening up possibility for future research.

\section{Results}

Who are AOTM Farmers in Kentucky?

Table 2 summarizes changes in the key characteristics of AOTM farmers in both the U.S. and Kentucky from 2002 to 2012. Over this period, the number of Kentucky AOTM farms increased by $11.3 \%$, while their average farm size and total sales decreased by $18.3 \%$ and $10.4 \%$, respectively. Despite the end of the federal tobacco program, the number of AOTM farms in Kentucky selling tobacco crop increased by $7.9 \%$.

Table 2 indicates that Kentucky AOTM differs from the national AOTM in several ways. First, the average size of AOTM farms in Kentucky is less than half the national average. From 2002 to 2012, U.S. AOTM farm numbers decreased by $5.1 \%$ while the number of Kentucky AOTM farms increased by $11.6 \%$. In Kentucky, the number of AOTM farms selling tobacco had a small increase of $7.9 \%$, while the number of U.S. AOTM farms selling tobacco decreased by $53.5 \%$. While the number of U.S. AOTM farms selling organic products saw a large increase, of $165.7 \%$, the number of Kentucky AOTM farms selling organic products increased by only $30.8 \%$. Conversely, the area of U.S. AOTM farmland treated with chemical fertilizers had a more sizeable decrease of $45.0 \%$, compared to Kentucky AOTM land (-27.6\%).

\section{Who Are AOTM Farmers Participating in the KyP Program?}

Table 3 shows the key characteristics of $\mathrm{KyP}$ farmers who participated in our survey. For comparison, a column is added to list the relevant data from the 2012 U.S. Census of Agriculture on Kentucky AOTM farmers. There are a number of expected and more interesting differences between KyP AOTM farmers and all KyP farmers; the most significant difference is that a higher share of $\mathrm{KyP}$ AOTM farmers has a past or present affiliation with tobacco. This finding reflects the state aim for the $\mathrm{KyP}$ program to facilitate the transition of tobacco-dependent farmers into a new agricultural economy. Regardless of the sales categories, the majority of $\mathrm{KyP}$ farmers sell direct to consumers, indicating the type of market outlet that the KyP program is promoting for farmers.

As shown in Table 3, in comparisons between the $\mathrm{KyP}$ program and the state, a statistically significant difference exists between KyP AOTM farms and the state AOTM farms. A higher percentage of AOTM farms is represented in the KyP program in $2011(18.4 \%)$ than the state average in 2012 $(11.3 \%)$. Also, the average farm size of KyP AOTM operations (368 acres or 149 hectares) is smaller than the state AOTM farm size (401 acres or $162 \mathrm{ha}$ ).

Relatively smaller rates of adoption of "alternative" or "sustainable" farming practices by KyP and state AOTM farmers suggest that they are not effectively capturing price premiums generated from USDA organic or GAP certification. Less than $40 \%$ of KyP AOTM farms produce organic products $(32.2 \%)$ or have GAP certification (38.6\%). Compared with 31.5\% of Kentucky AOTM farms, $76.3 \%$ of KyP AOTM farms use pesticides and herbicides.

Direct-to-consumer sales are the most important high-value, differentiated product practice for KyP AOTM farms. Compared with the state AOTM, a larger proportion of $\mathrm{KyP}$ AOTM farms $(84.7 \%)$ sell directly to consumers. Although the number is small (23.3\%), a larger percent of KyP AOTM farms participate in agritourism than the state counterpart.

\section{How Does the KyP Program Affect AOTM?} The next set of findings analyzes the difference between two sets of dependent variables for $\mathrm{KyP}$ AOTM farmers and all other KyP farmers as follows:

(a) Dependent variable: Did KyP help to increase your sales?

- Independent Variables: market outlets, farming practices, products sold, and marketing practices

(b) Dependent variable: Is the KyP program valuable in helping to market your business?

- Independent Variables: market outlets, 
farming practices, products sold, and marketing practices

As shown in Table 4, compared to all other KyP-participant farmers a higher percentage of $\mathrm{KyP}$ AOTM farmers report both an increase in sales $(38.6 \%)$ and a positive value for the program in marketing their business $(77.6 \%)$. The mean years of participation were four years for AOTM farmers and three years for all others. The number of years participating in the program has no significant association to whether or not respondents reported an increase in sales.

The next step in the comparison was to identify any distinguishing characteristics between those who indicated benefits from $\mathrm{KyP}$ and those who reported otherwise, for both groups. As shown in Table 4, the findings indicate that for both groups, both dependent variables are independent of market outlets used (e.g., direct sales or contract), farming practices (e.g., organic or conventional), and products sold for income (e.g., beef or vegetables/fruits), with no association at significance level of 0.05 .

Findings indicate that both outcome variables for both groups are dependent on several marketing practices, with an association less than significance level of 0.05 . These marketing practices include using the logo on products and using the logo for other marketing (that is, marketing materials other than the product itself, such as banners or brochures), which represent knowledge and skills developed through the KyP program. Those who reported an increase in sales appear to be those using the logo on their product and on other marketing tools, and who report that their marketing ability has increased due to the program. Members who find value in the program tend to be those who use the logo for other marketing tools, feel their marketing knowledge and ability have increased, and market their products better and more extensively because of the KyP program. Overall, our findings suggest that using the logo for marketing tools other than for the product is a valuable practice for members.

Both groups responded similarly to the questions about how the $\mathrm{KyP}$ program benefited them. They seem to enthusiastically embrace the use of the logo on their products and for other marketing. Of note, a higher percentage of AOTM farmers compared to all others feel the program has a positive impact on their business. Overall, an

Table 4. Impact of Kentucky Proud ${ }^{\mathrm{TM}}$ on Farmers, $2011(N=320)$

\begin{tabular}{|c|c|c|c|c|}
\hline \multirow[b]{2}{*}{$\begin{array}{l}\text { Operational } \\
\text { Characteristics }\end{array}$} & \multicolumn{2}{|c|}{$\begin{array}{c}\text { Did KyP help } \\
\text { increase sales? }\end{array}$} & \multicolumn{2}{|c|}{$\begin{array}{l}\text { Is KyP program } \\
\text { valuable? }\end{array}$} \\
\hline & $\begin{array}{l}\text { All Others } \\
(N=261)\end{array}$ & $\begin{array}{l}\text { AOTM } \\
(N=59)\end{array}$ & $\begin{array}{l}\text { All Others } \\
(N=261)\end{array}$ & $\begin{array}{l}\text { AOTM } \\
(N=59)\end{array}$ \\
\hline Yes (count) & 71 & 22 & 184 & 45 \\
\hline Yes (\%) & $28.1 \%$ & $38.6 \%$ & $72.7 \%$ & $77.6 \%$ \\
\hline Direct to Consumer Sales & $29.3 \%$ & $35.3 \%$ & $73.4 \%$ & $76.5 \%$ \\
\hline Agri-Tourism & $37.0 \%$ & $50.0 \%$ & $75.0 \%$ & $80.0 \%$ \\
\hline Organic & $33.3 \%$ & $53.9 \%$ & $79.3 \%$ & $76.9 \%$ \\
\hline Chemicals-Fertilizers & $28.1 \%$ & $28.1 \%$ & $72.1 \%$ & $71.9 \%$ \\
\hline Use Logo on Products & $34.2 \% * * *$ & $44.8 \%{ }^{*}$ & $83.5 \% * * \star$ & $75.9 \%$ \\
\hline Use Logo for Other Marketing Tools a & $35.0 \% * *$ & $47.8 \% * *$ & $82.5 \%^{* * *}$ & $82.6 \% * *$ \\
\hline Increase in Marketing Knowledge & $34.9 \%^{* * *}$ & $47.6 \%$ & $90.2 \%^{* * *}$ & $90.5 \%$ ** \\
\hline Increase in Ability to Market & $40.4 \%^{* * *}$ & $48.2 \%^{*}$ & $92.9 \% * * *$ & $92.6 \% * * *$ \\
\hline Market Products Better & $40.7 \%^{* * *}$ & $47.8 \%$ & $93.2 \%^{* * *}$ & $91.3 \%$ *** \\
\hline Market Products More & $40.6 \%^{* * *}$ & $44.4 \%$ & $93.7 \% * * *$ & $100.0 \% * * *$ \\
\hline
\end{tabular}

Source: Fisher, 2012. * $p<0.05, * * p<0.01, * * * p<0.001$

a May include such marketing tools as websites, brochures, banners, bags, etc. 
increase in marketing knowledge, ability, and skills is correlated with member perception of how valuable the $\mathrm{KyP}$ program is.

\section{Discussion}

Midsize farms in the U.S. have been declining in numbers, and this a shifting farm structure negatively affects the quality of life of farm families and their communities. Could state-sponsored agricultural branding and marketing campaigns be a viable option for AOTM farmers? A label can be used to signify alternative identity and legitimacy, the two main features Mount (2012) cites as necessary for scale development.

Our findings indicate potential opportunities and limitations for the $\mathrm{KyP}$ program as a strategy for AOTM. The KyP program is a marketing campaign that has the goals of benefitting farmers and the agricultural sector economically. Our study suggests that as a marketing strategy, the KyP program is indeed serving AOTM. First, $\mathrm{KyP}$ has a higher percentage of AOTM farmers participating in the program (18.4\%), compared to the percentage of AOTM farmers in the state $(11.3 \%)$. Second, $77.6 \%$ of these farmers find the program to be of value in helping to market their business. The intent of the KyP program is to help farmers differentiate their products by using a label. According to the KyP consumer awareness survey conducted by the KDA in 2010, the logo has received a high percentage $(70 \%)$ of consumer awareness (Fisher, 2013). The program offers members opportunities through its marketing strategy. The logo and various program services help member farmers lower the cost of marketing their products and businesses. While the program does not have any strict certification process, farmers can save on costs associated with monitoring compliance.

While the $\mathrm{KyP}$ program has the potential for differentiating products to help capture price premiums, more than half of KyP AOTM farmers (61.4\%) have not yet seen economic gains from the program, even when using the well-recognized logo on their products (44.8\%). Who is benefiting from the logo's branding, then? Here lies the limitation of a state branding program for AOTM farmers. As pointed out previously, the KyP Program defines eligible "local" products broadly, to include any agricultural products grown, raised, processed, and/or packaged in Kentucky. This means that purchase of a KyP product does not guarantee direct benefits to Kentucky farmers. For example, a bag of coffee roasted and packaged by a Kentucky-based company in the state can have a "Kentucky Proud" label, with no direct benefits to Kentucky farmers.

With this loose definition of "Kentucky

Proud" products, can AOTM farmers count on the label to signal their products as unique from their competitors in order to build identity and promote their legitimacy? Would the inclusion of a state-oforigin percentage requirement in the KDA's $\mathrm{KyP}$ definition benefit more AOTM farmers by generating an increase in sales? Should the state incorporate other attributes, such as environmental and social justice indicators, to the state-brand label? These are questions Kentucky and other states should consider when making decisions on future agricultural development in their states. Policymakers can assess their existing state marketing strategies, starting with their branding campaign, because most states already have some type of program in place, such as a logo. In the case of Kentucky, although AOTM farmers find value in the program marketing tools, the knowledge, skills, and abilities gained through the program do not necessarily translate into economic gains for member farmers.

\section{Conclusion}

Although our findings show the potential of state branding campaigns to help farmers differentiate their products, further research is needed to track the long-term impact of different types of agricultural branding campaigns at multiple levels. Some critical questions to be investigated: How does a given state branding campaign affect different types of farm enterprises? What aspects of the campaign benefit and constrain participating farm enterprises? How does the campaign affect the economic, environmental, and social sustainability of agriculture within the state? An effective longitudinal research effort must be more comprehensive, therefore, by combining the existing research instruments that examine the efficacy of marketing and branding programs on producers, consumers, 
and the state economy.

Additionally, we need a systematic comparative analysis of state branding campaigns using the same research instruments to answer the above questions. Such a study will allow us to identify "good practices" in state-sponsored marketing programs and facilitate collaborations between states to further improve the effectiveness of these programs.

This study is our first step in developing research instruments for tracking outcomes for farmers participating in state branding campaigns. We plan to contribute to Kentucky's efforts to monitor and evaluate the KyP program's impact on small-scale and AOTM farmers. Moreover, we hope that this study will help start a conversation among researchers to develop a longitudinal comparative study on state-sponsored branding campaigns and marketing programs in the United States.

\section{Acknowledgments}

This project was partly supported by generous grants from the Kentucky Department of Agriculture and the Rural Sociological Society Master's Thesis Research Award. This research was also funded by the USDA-NIFA Multistate Research Fund NC 1198, "Renewing an Agriculture of the Middle: Value Chain Design, Policy Approaches, Environmental and Social Impacts." The authors thank Patrick Mooney, Tim Woods, Bob Perry, and anonymous reviewers for providing insightful comments on the previous drafts. The views and opinions expressed in this article are those of the authors alone.

\section{References}

Caporelli, A. (2011). Local foods initiatives. Presentation at Governor's Office of Agricultural Policy (GOAP) Conference, Bowling Green, Kentucky.

Carpio, C. E., \& Isengildina-Massa, O. (2009a). Consumer willingness to pay for locally grown products: The case of South Carolina. Agribusiness, 25(3), 412-426. http://dx.doi.org/10.1002/agr.20210

Carpio, C. E., \& Isengildina-Massa, O. (2009b). Measuring the potential economic impact of a regional agricultural promotion campaign: The case of South Carolina. Paper presented at the Southern Agricultural Economics Association Annual Meeting, Atlanta, Georgia.

Clancy, K. (2010). A priority research agenda for agriculture of the middle. Retrieved from http://www.agofthemiddle.org/pubs/AOTM ewsearch.pdf

Davis, J. A. (2012). Locally grown produce as a marketing strategy: Producer perceptions of state-sponsored marketing programs (Master's thesis). University of Tennessee, Knoxville, Tennessee. Retrieved from http://trace.tennessee.edu/utk gradthes/1147

Definitions, KY Rev. Stat. (2008). 260.16. Definitions for KRS 260.016 to 260.019. Retrieved from http://www.lrc.ky.gov/statutes/statute.aspx?id+12 $\underline{530}$

Diamond, A., \& Barham, J. (2011). Money and mission: Moving food with value and values. Journal of Agriculture, Food Systems, and Community Development, 1(4), 101-117. http://dx.doi.org/10.5304/jafscd.2011.014.013

Dillman, D. A., Smyth, J. D., \& Christian, L. M. (2008). Internet, mail, and mixed-mode surveys: The tailored design method ( $3^{\text {rd }}$ ed.). Hoboken, New Jersey: Wiley.

Fisher, A. (2012). How proud is Kentucky food? A survey of environmental conditions of local food. Kentucky Journal of Anthropology and Sociology, 2(2), 101-113. Retrieved from http://ask.anthroniche. com/wp-content/uploads/2015/10/kjas 2 2 20122 fisher.pdf

Fisher, A. (2013). How proud is Kentucky food? A look at the commonwealth's agricultural brand in the post-tobacco landscape. Sustain, 27, 55-65. Retrieved from http://louisville.edu/kiesd/sustainmagazine/SUSTAIN-27.pdf

Goldschmidt, W. (1978 [1947]). As you sow: Three studies in the social consequences of agribusiness. Montclair, New Jersey: Allanheld, Osmun.

Governor's Office of Agricultural Policy [GOAP]. (n.d.). We are here to belp you. Retrieved from http://agpolicy.ky.gov

Govindasamy, R., Italia, J., \& Thatch, D. (1999). Consumer attitudes and response toward statesponsored agricultural promotion: An evaluation of the Jersey Fresh program. Journal of Extension, 37(3), 60-69. 
Govindasamy, R., Schilling, B. J., Sullivan, K., Turvey, C. G., Brown, L., \& Puduri, V. (2004). Returns to the Jersey Fresh promotional program: The impacts of promotional expenditures on farm cash receipts in New Jersey (Publication No. 36728). Rutgers, New Jersey: Rutgers University, Department of Agricultural, Food and Resource Economics.

Green, G. (1985). Large-scale farming and the quality of life in rural communities: Further specifications of the Goldschmidt hypothesis. Rural Sociology, 50(2), 262-274.

Hinrichs, C., \& Jensen, E. (2006). State identity labeling of food and agricultural products: Organization, governance and outcomes. Paper presented at the Rural Sociological Society annual meeting, Louisville, Kentucky.

Hinrichs, C. C., \& Lyson, T. A. (2007). Remaking the North American food system: Strategies for sustainability. Lincoln: University of Nebraska Press.

Hu, W., Onozaka, Y., \& McFadden, D. T. (2011). What are the economic welfare effects of local food marketing? Exploring impacts with the case of Colorado apples. Paper presented at Agricultural and Applied Economics annual meeting, Pittsburgh, Pennsylvania.

Infanger, C., Maurer, R., \& Palmer, G. (2008). An evaluation of agricultural development board investments in Kentucky agriculture 2001-2007: Non-model projects, model programs, and the Kentucky Agricultural Finance Corporation (Evaluation Report). Lexington: University of Kentucky, Kentucky Agricultural Finance Corporation. Retrieved from http://agpolicy.ky.gov/board/Pages/default.aspx

Kentucky Department of Agriculture. (n.d.). Kentucky Proud. Retrieved November 22, 2015, from http://www.kyagr.com/marketing/kentuckyproud.html

Kirschenmann, F., \& Stevenson, S. (2015). Agriculture of the middle. Retrieved from http://ngfn.org/ resources/ngfn-database/knowledge/110304 agofthemiddleppt.pdf

Kirschenmann, F., Stevenson, S., Buttel, F., Lyson, T., \& Duffy, M. (2013). Characterizing agriculture of the middle and values-based food supply chains. Retrieved from http://www.agofthemiddle.org/

Kirschenmann, F., Stevenson, S., Clancy, K., Marlow, S., Simmons, R., Smith, S., \& Yee, L. (2013). Why worry about the agriculture of the middle? Retrieved from http://www.agofthemiddle.org/papers/whitepaper 2.pdf

Lev, L., \& Stevenson, G. W. (2013). Values-based food supply chains: An introduction to nine case studies. Retrieved from http://www.cias.wisc.edu/wpcontent/uploads/2013/04/introsectionfinal 072513.pdf

Lobao, L. E., Schulman, M. D., \& Swanson, L. E. (1993). Still going: Recent debates on the Goldschmidt hypothesis. Rural Sociology, 58(2), 277-288. http://dx.doi.org/10.1111/j.15490831.1993.tb00495.x

Lyson, T. A., Stevenson, G. W., \& Welsh, R. (2008). Preface. In T.A. Lyson, G.W. Stevenson, \& R. Welsh. (Eds.), Food and the mid-level farm: Renewing an agriculture of the middle (pp. xi-xvii). Cambridge, Massachusetts: MIT Press. http://dx.doi.org/ $10.7551 /$ mitpress /9780262122993.001.0001

MacDonald, J. M., Korb, P., \& Hoppe, R. A. (2013). Farm size and the organization of U.S. crop farming (Economic Research Report No. ERR-152). Washington, D.C.: U.S. Department of Agriculture, Economic Research Service. Retrieved from http://www.ers.usda.gov/media/1156726/ err152.pdf

Mount, P. (2012). Growing local food: Scale and local food systems governance. Agriculture and Human Values, 29(1), 107-121. http://dx.doi.org/10.1007/s10460-011-9331-0

Onken, K. A., Bernard, J. C., \& Pesek, J. D., Jr. (2011). Comparing willingness to pay for organic, natural, locally grown, and state marketing program promoted foods in the mid-Atlantic region. Agricultural and Resource Economics Review, 40(1), 33-47.

Patterson, P. M. (2006). State-grown promotion programs: Fresher, better? Choices, 21(1), 41-46.

Peters, D. J. (2002). Revisiting the Goldschmidt hypothesis: The effect of economic structure on socioeconomic conditions in rural Midwest (Technical Paper P-0702-1). Missouri Economic Research and Information Center, Missouri Department of Economic Development. Jefferson City, Missouri.

Stevenson, S. (2009). Values-based food supply chains: Executive summary. Madison, WI: University of Wisconsin, Center for Integrated Agricultural Systems, Retrieved from http://www.agofthe middle.org/pubs/vcexec.sum.pdf

Timms, L. L., \& Schulte, K. (2013). 2012 Iowa dairy farm survey (Animal Industry Reports AS 659, ASL R2798). Ames: Iowa State University Extension and Outreach. Retrieved from http://lib.dr.iastate.edu/ans_air/vol659/iss1/49 
Uematsu, H., \& Mishra, A. K. (2011). Use of direct marketing strategies by farmers and their impact on farm business income. Agricultural and Resource Economics Review, 40(1), 1-19.

U.S. Department of Agriculture. (2002, 2012). The Census of Agriculture. Washington, D.C.: U.S. Department of Agriculture, National Agricultural Statistics Service (USDA-NASS). Retrieved from http://www.agcensus.usda.gov

University of Minnesota, Food Industry Center. (2014). State level food system indicators. St. Paul, Minnesota: Food Industry Center, Department of Applied Economics, University of Minnesota.
Velandia, M., Davis, J. A., Lambert, D. M., Clark, C. D., Wilcox, M. D., Jr., Wszelaki, A., \& Jensen, K. (2012). Factors affecting producer awareness of state programs promoting locally grown foods: The case of fruit and vegetable growers in Tennessee. Journal of Food Distribution Research, 43(2), 14-28.

Walz, E. (2004). Final results of the fourth national organic farmers' survey: Sustaining organic farms in a changing organic marketplace. Santa Cruz, California: Organic Farming Research Foundation. 
Appendix A. Survey Questions Used to Analyze Types of Member Farming Practices, Products

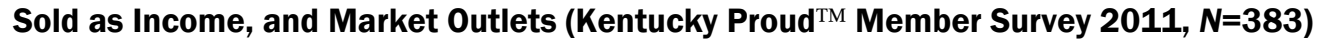

\begin{tabular}{|c|c|}
\hline $\begin{array}{l}\text { Q1. Do you practice any of the growing methods listed } \\
\text { below? (Select one in each row. } 0=\text { No, } 1=\text { Yes) }\end{array}$ & $\begin{array}{l}\text { Q2. Do you use any of the items listed below for your } \\
\text { operation? (Select one in each row. } 0=\text { No, } 1=\text { Yes) }\end{array}$ \\
\hline $\begin{array}{l}\text { Seed saving } \\
\text { Certified organic } \\
\text { Organic, not certified } \\
\text { Conventional } \\
\text { Biodynamic } \\
\text { Permaculture } \\
\text { Holistic management } \\
\text { Cover crops } \\
\text { Composting } \\
\text { Spray } \\
\text { Tillage } \\
\text { Irrigation } \\
\text { No-till } \\
\text { Rotational intensive grazing } \\
\text { Grass-feed livestock }\end{array}$ & $\begin{array}{l}\text { Herbicides } \\
\text { Pesticides } \\
\text { Soil amendments } \\
\text { Livestock feed purchased off the farm } \\
\text { Livestock supplements } \\
\text { Antibiotics for livestock } \\
\text { Genetically modified seed }\end{array}$ \\
\hline $\begin{array}{l}\text { Q3. Which farm activities listed below do you count } \\
\text { as your farm's income? (Select one each row. } 0= \\
\text { No, } 1 \text { = Yes) } \\
\text { Tobacco } \\
\text { Hay } \\
\text { Beef } \\
\text { Poultry } \\
\text { Swine } \\
\text { Horses } \\
\text { Dairy } \\
\text { Vegetables/Fruits } \\
\text { Grains } \\
\text { Aquaculture } \\
\text { Agri-tourism } \\
\text { Other }\end{array}$ & 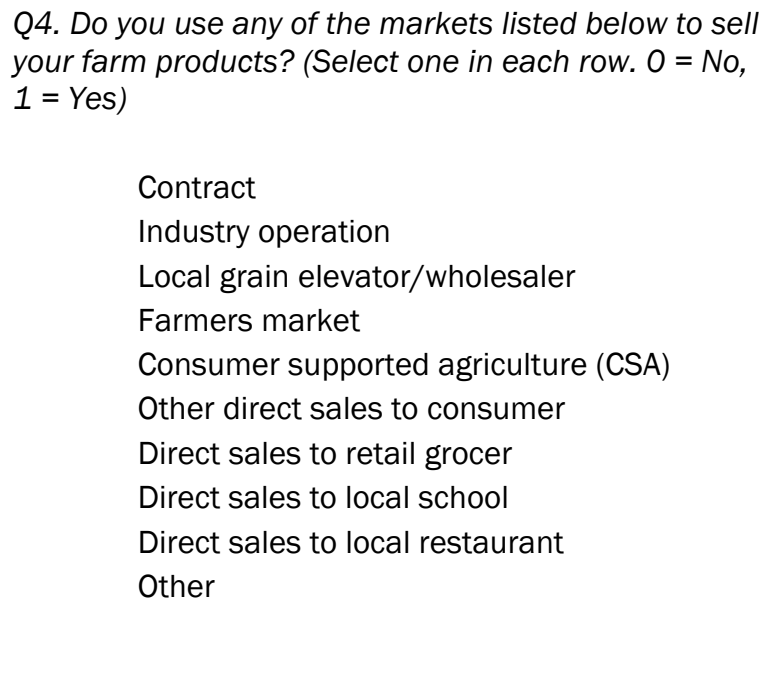 \\
\hline
\end{tabular}

